\title{
Pengembangan Hidung Elektronik untuk Klasifikasi Mutu Minyak Goreng dengan Metode Principal Component Analysis
}

\author{
Soca Baskara*1, Danang Lelono ${ }^{2}$, Triyogatama Wahyu Widodo ${ }^{3}$ \\ ${ }^{1}$ Prodi Elektronika dan Instrumentasi Jurusan Ilmu Komputer dan Elektronika, FMIPA UGM \\ ${ }^{2}$ Departemen Ilmu Komputer dan Elektronika, FMIPA UGM \\ e-mail: *1.
}

\begin{abstract}
Abstrak
Keberadaan minyak goreng yang dicampur dengan bahan berbahaya sulit untuk dideteksi menggunakan indera penciuman masusia dan hanya dapat dideteksi oleh peralatan canggih. Namun peralatan tersebut membutuhkan biaya tinggi dan memerlukan seorang ahli dalam pengoperasiannya.

Electronic nose berbasis larik sensor gas tak terseleksi (unselected) model statis telah berhasil dibuat untuk mengklasifikasi aroma sampel minyak goreng murni dan campuran. Pada ruang sensor terdapat larik sensor yang terdiri dari sensor MQ-9, TGS-2600, MQ-2, MQ-4, $T G S-2620$, dan TGS-822 serta sebuah sistem pertukaran panas yang mampu untuk mereduksi temperatur uap sampel. Ruang sampel dan ruang sensor terrbuat dari bahan stainless steel berbentuk tabung. Pengujian sistem electronic nose dilakukan dengan memanaskan sampel berupa minyak goreng jenis minyak sawit dan minyak kelapa beserta campurannya berupa oli bekas, lilin, dan solar hingga suhu $300{ }^{\circ} \mathrm{C}$ untuk memunculkan aromanya. Setelah aroma berhasil dideteksi oleh electronic nose selanjutnya dilakukan klasifikasi dengan menggunakan metode PCA.

Hasil penelitian menunjukkan respon keluaran sensor yang stabil dan keluaran dari score plot data minyak goreng murni baik minyak sawit murni maupun minyak kelapa murni dapat terklasifikasi dengan minyak goreng campuran.
\end{abstract}

Kata kunci-larik sensor, termodinamika, ruang sensor, respon sensor.

Abstract
The existence of cooking oil which is mixed with dangerous material is very difficult to be detected by human olfactory system yet can be detected by sophisticated equipment. However, the equipment is very expensive and require an expert to operate it.

Static system of electronic nose based on unselected gas sensor array has been built for classifying pure cooking oil's odour and mixed cooking oil's odour. Sensor array consist of sensor MQ-9, TGS-2600, MQ-2, TGS-2620, and TGS-822 along with a heat exchanger system that can reduce the temperature of sample's odour. The sample chamber and sensor chamber are made from stainless steel with cylinder shape. The system tested by boiling the sample consist of each pure cooking oil form both palm and coconut oil with its mixture such as used lubricant, candle, and diesel fuel up to $300{ }^{\circ} \mathrm{C}$ to realese its odour. After the odour has been detected by electronic nose the next step is to classifying the data with PCA method.

The result show that the response of sensor's output is stable and the output of score plot from each pure cooking oil's data from both palm and coconut oil can be well-classified from the mixed cooking oil.

Keywords-sensor array, thermodynamics, sensor chamber, sensor response. 



\section{PENDAHULUAN}

$M$ inyak goreng merupakan medium penggoreng bahan pangan yang banyak dikonsumsi masyarakat luas. Minyak goreng adalah minyak nabati yang telah dimurnikan dan dapat digunakan sebagai bahan pangan. Minyak ini selain memberikan nilai kalori paling besar diantara zat gizi lainnya juga dapat memberikan rasa gurih, tekstur dan penampakan bahan pangan menjadi lebih menarik, serta permukaan yang kering [1].

Minyak goreng dapat diproduksi dari berbagai macam bahan mentah, misalnya kelapa, kopra, kelapa sawit, kacang kedelai, biji jagung (lembaganya), biji bunga matahari, biji zaitun (olive), dan lain-lain [2]. Kurang lebih 290 juta ton minyak dikonsumsi setiap tahunnya. Banyaknya permintaan akan bahan pangan digoreng merupakan suatu bukti yang nyata mengenai betapa besarnya jumlah bahan pangan digoreng yang dikonsumsi masyarakat dari segala usia [3].

Oleh karena minyak goreng telah menjadi kebutuhan pokok, maka diperlukan standar mutu dari minyak goreng. Standar mutu minyak goreng di Indonesia mengacu pada Badan Standardisasi Nasional tentang minyak goreng yang meliputi kriteria-kriteria yang harus dipenuhi[4]. Jika diamati lebih lanjut, kriteria standar kualitas minyak masih mengalami perluasan berdasarkan tingkat degradasi mutu seperti masa kadaluarsa, timbulnya bau tengik, serta lama pemakaian yang berulang-ulang. Pemakaian yang berulang-ulang ini dilakukan untuk menekan biaya produksi, dengan kata lain minyak goreng digunakan kembali setelah beberapa kali proses penggorengan. Apalagi demi mengurangi biaya produksi biasanya oknum pedagang melakukan pencampuran minyak goreng dengan bahan-bahan berbahaya seperti lilin, oli bekas, dan solar

Apabila mengalami pemanasan yang berlebih $\left(200{ }^{0} \mathrm{C}-250{ }^{\circ} \mathrm{C}\right)$ mutu dari minyak goreng akan mengalami degradasi yang akan mengakibatkan keracunan dalam tubuh dan berbagai macam penyakit, misalnya diare, pengendapan lemak dalam pembuluh darah, bahkan kanker. Sedangkan jika ditinjau dari komposisi kimianya, minyak goreng yang sudah mengalami pemanasan pada suhu tinggi mengandung senyawa-senyawa bersifat karsinogenik [5]. Senyawa-senyawa kimia tersebut antara lain peroksida, epioksida, dan lain sebagainya [1]. Hasil temuan terbaru menunjukkan bahwa untuk beberapa jenis minyak goreng saat pemakaiannya juga dihasilkan racun hidrokarbon berupa alkybenzene [6][7].

Analisa mutu minyak goreng dengan menggunakan analitik kimia standar membutuhkan ahli dan biaya yang tinggi. Untuk itu dibutuhkan sebuah instrument yang dapat mengklasifikasi minyak goreng yang murni dengan minyak goreng yang dicampur dengan bahan-bahan berbahaya berdasarkan aroma dari uap panas yang dihasilkan.

Teknologi electronic nose (e-nose) adalah contoh teknologi yang prinsip kerjanya meniru prinsip kerja hidung manusia. Electronic nose disusun oleh beberapa sensor gas yang berfungsi untuk mendeteksi bau / aroma yang meniru struktur larik syaraf penciuman dalam olfaktori manusia. Itulah sebabnya, keluaran e-nose dapat berupa pola-pola yang mewakili masing-masing bau / aroma sehingga dapat diterapkan untuk identifikasi, perbandingan, kuantifikasi dan klasifikasi berdasarkan aroma. [8].

Peneltian ini difokuskan pada rancang bangun e-nose yang digunakan untuk mengklasifikasi pola degradasi mutu minyak goreng jenis minyak sawit dan minyak kelapa murni terhadap minyak goring jenis kelapa dan sawit campuran berdasarkan aroma uap hasil pemanasan.

\subsection{Analisis Sistem}

\section{METODE PENELITIAN}

Analisis pada sistem electronic nose terdiri dari bahan, peralatan, pengujian sampel, pengolahan data sampel, dan pengambilan data sampel. 



\subsubsection{Bahan}

a. Sampel Minyak Goreng jenis minyak kelapa dan minyak sawit.

b. Bahan pencampur minyak goreng yang terdiri dari oli bekas, lilin, dan solar.

\subsubsection{Peralatan}
a. Sensor gas TGS822, TGS2620, TGS2600, MQ2, MQ9, dan MQ4
b. Sensor temperatur (termokopel dan LM35)
c. Mikrokontroller Arduino Mega 2620
d. Power Supply
e. Kompor gas
f. Casing Acrylic

\subsubsection{Pengujian Sampel}

Dalam proses pengujian, sampel berupa minyak goreng ditaruh kedalam suatu wadah (chamber) kemudian dipanaskan hingga mencapai temperatur $300^{\circ} \mathrm{C}$ untuk mengeluarkan uap dari sampel minyak goreng. Karena sampel dipanaskan hingga suhu $300^{\circ} \mathrm{C}$, maka diperlukan sebuah termokopel yang mampu untuk membaca kenaikan suhu hingga $300^{\circ} \mathrm{C}$. Setelah uap sampel keluar, selanjutnya uap akan dialirkan menuju ke ruang sensor yang didalamnya terdapat rangkaian array sensor yang merespon bau yang dihasilkan oleh sampel tersebut. Ruang sampel dan ruang sensor dirancang dengan metode aliran udara tipe static dimana aliran udara berlangsung tanpa bantuan gas karier. Alasan dibuat tipe static karena ingin mengetahui seberapa efektif respon dari array sensor jika disusun secara static sehingga dapat diketahui kelebihan dan kekurangannya jika ruang sensor dibuat dengan tipe static [9]. Pengujian sampel dilakukan dalam beberapa kali untuk mendapatkan nilai tegangan keluaran yang konstan dan akurat.

\subsubsection{Pengolahan data sampel}

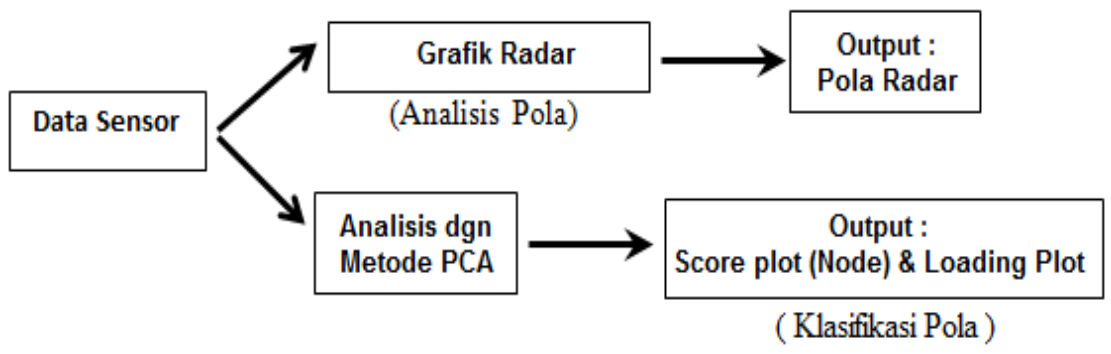

Gambar 1 Arsitektur sistem pengolahan data sensor

Gambar 1 dapat dijabarkan untuk pengolahan data yang diperoleh dari nilai tegangan keluaran tiap sensor $(\mathrm{mV})$. Pengolahan data dibagi menjadi 2 langkah secara tidak langsung. Yang pertama, untuk mengetahui repeatabilitas sistem $e$-nose, data sensor berupa nilai tegangan keluaran tiap sensor $(\mathrm{mV})$ dilakukan pengolahan analisis pola dengan grafik radar menggunakan Ms.Excel sehingga diperoleh output berupa pola radar untuk tiap-tiap sensor. Kemudian yang kedua, untuk melakukan klasifikasi tiap-tiap sampel dilakukan pengolahan analisis dengan menggunakan metode statistik multivarian PCA (Principle Component Analysis) dimana diperoleh output berupa score plot (Node) dan loading plot untuk memperoleh klasifikasi dan korelasi dari keseluruhan sampel yang diuji.

Pada penelitian ini sampel yang digunakan berupa minyak goreng jenis minyak sawit dan minyak kepala dengan beberapa campurannya. Sampel dipanaskan hinga suhu $300^{\circ} \mathrm{C}$. Data respon sensor yang diperoleh dari $\mathrm{ADC}$ sensor pada mikrokontroler kemudian dikirim melalu port USB menuju komputer (PC). Pada gambar 2 dijelaskan grafik untuk satu kali pengambilan 

data didapatkan nilai maksimum dan minimum pada masing-masing sensor, dari nilai tersebut akan digunakan untuk proses PCA dengan persamaan (1).

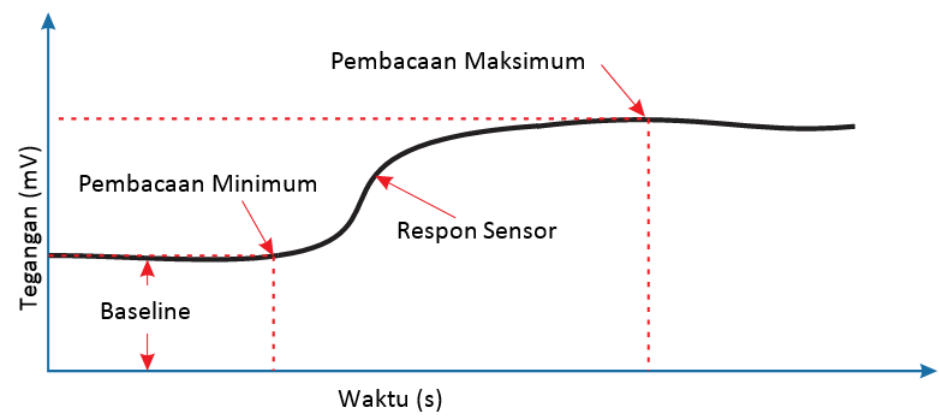

Gambar 2. Pengambilan data

$$
\begin{gathered}
X i s=X \max -X \min \\
\text { dengan: } \\
X=\text { respon sinyal sensor } \\
i=\text { data ke } 1,2,3,4,5 \\
s=\text { sensor } 1,2,3,4,5,6
\end{gathered}
$$

Karena setiap sampel dilakukan lima kali percobaan maka akan didapatkan sebanyak 5 data. Untuk mencari nilai rerata per-sampel dihitung dengan persamaan (2).

$$
\bar{X} \text { is }=\frac{2 \text { Xis }}{5}, \bar{X}=\text { Rata }- \text { rata }
$$

Data rerata ini digunakan untuk proses grafik radar. Kemudian dengan menggunakan Principle Component Analysis (PCA) dihasilkan 2 keluaran yaitu grafik PCA node dan grafik ini berfungsi untuk mengetahui titik (node) setiap variabel data yang secara otomatis akan mengelompokkan/mengklasifikasikan sendiri keluaran data tersebut.

\subsection{Perancangan sistem secara keseluruhan}

Diagram blok sistem electronic nose yang dirancang pada penelititan ini, terdiri atas larik sensor gas, pemroses sinyal, user interface pada komputer yang mengambil dan menampilkan data secara real time on line.

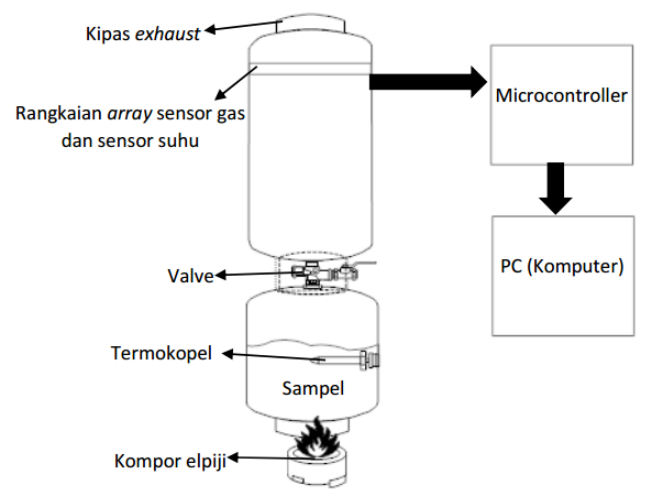

Gambar 3 Diagram blok rancangan sistem e-nose secara keseluruhan. 

Gambar 3 menjelaskan bahwa sampel minyak goreng diletakkan pada ruang pemanas, dan dipanaskan hingga mencapai suhu $300^{\circ} \mathrm{C}$ menggunakan kompor gas, kemudian aroma yang dihasilkan dialirkan menuju ruang sensor. Di dalam ruang sensor terdapat enam sensor gas yang berbeda jenis yang mengkonversi aroma yang dihasilkan sampel menjadi tegangan keluaran dalam $\mathrm{mV}$. Tegangan keluaran dari sensor yang menghasilkan sinyal analog kemudian dikonversi menjadi sinyal digital lalu disimpan dan ditampilkan dalam bentuk grafik yang selanjutnya dilakukan analisis untuk mengklasifikasi minyak sawit dan minyak kelapa murni dengan minyak sawit dan minyak kelapa yang sudah terdegradasi mutunya.

Perangkat lunak (software) yang digunakan dalam penelitian ini terdiri atas program yang dibuat menggunakan menggunakan Lab View dan Arduino IDE. Program dibuat sebagai sarana untuk menjalankan kerja sensor saat proses akuisisi data secara otomatis. Diagram alir rancangan program secara umum ditunjukkan oleh Gambar 4

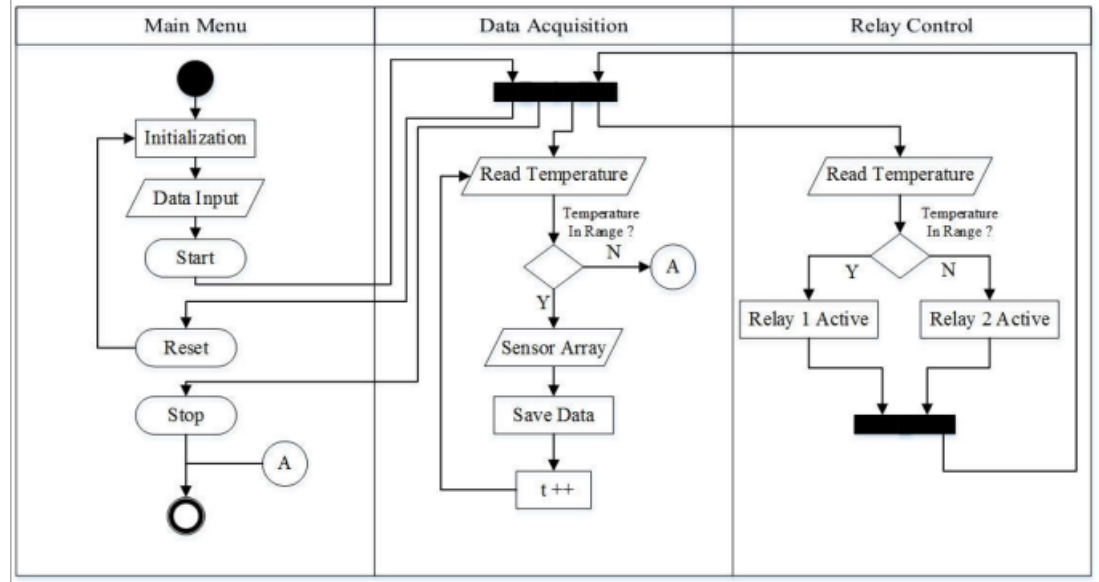

Gambar 4 Diagram alir sistem e-nose secara keseluruhan

\subsection{Perancangan Perangkat Keras (Hardware)}

\subsubsection{Perancangan rangkaian skematik sistem secara keseluruhan}

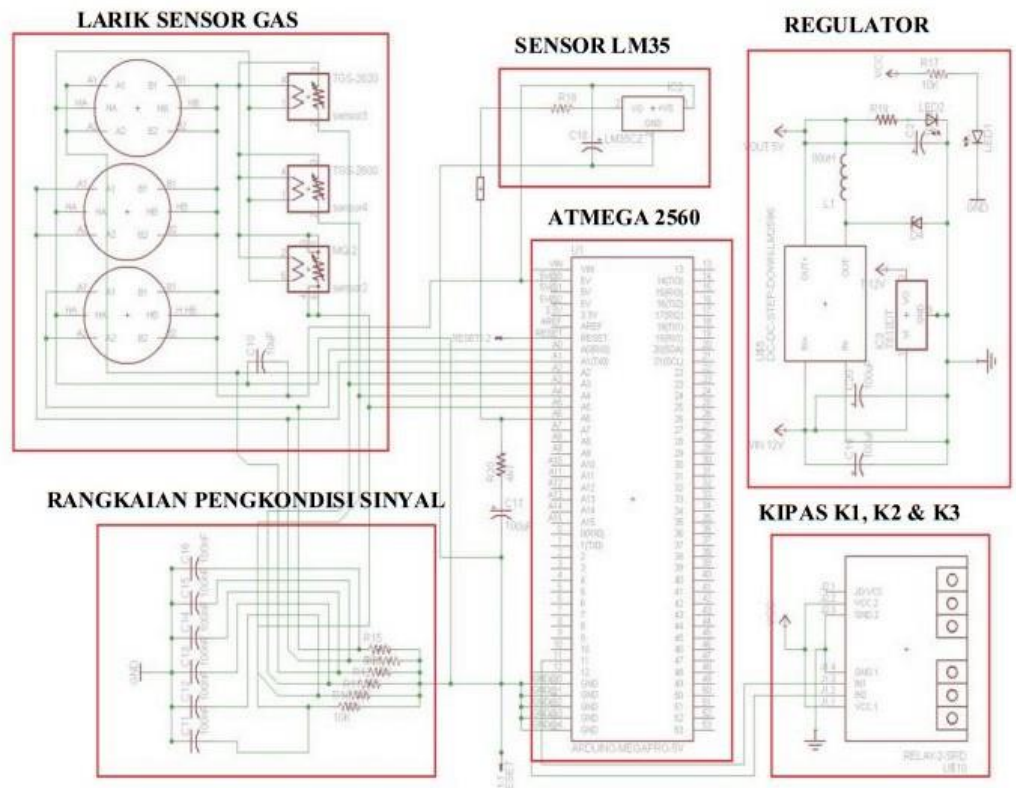

Gambar 5 Rangkaian sistem secara keseluruhan 

Gambar 5. merupakan rancangan rangkaian secara keseluruhan dari sistem. Selain komponen inti dari penelitian ini yaitu enam buah sensor gas yang digunakan sebagai indikator output dari data yang akan diolah, terdapat juga beberapa komponen pendukung lain seperti kontroler yang menggunakan Arduino Mega 2650, regulator yang menghasilkan tegangan output sebesar $5 \mathrm{~V}$ dan $12 \mathrm{~V}$, komponen sensor suhu sampel yang menggunakan termokopel jenis K dengan pengolah data Maxim MAX6675. Sensor suhu LM35 juga digunakan sebagai komponen safety pada sistem.

\subsubsection{Rancangan ruang sensor dan ruang sampel}

Ruang sampel dan ruang sensor dirancang dengan bahan stainless steel dan dengan bentuk tabung silinder. Gambar 6 menunjukkan rancangan ruang sampel dan ruang sensor.

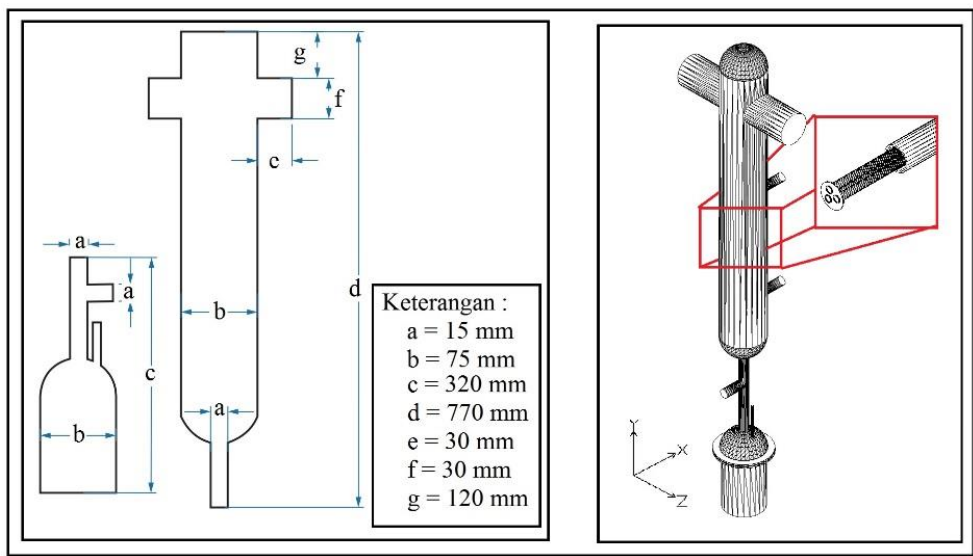

Gambar 6 Rancangan ruang sampel dan ruang sensor

\subsection{Rancangan Perangkat Lunak (Software)}

Untuk mencapai tujuan dari penelitian ini dirancang sebuah program yang mampu untuk mengakuisisi data pembacaan dari larik sensor gas dan sensor temperatur, selain itu pada program yang dirancang harus mampu untuk mengaktifkan kipas yang digunakan untuk mengalirkan aroma uap dari sampel yang dipanaskan. Untuk menghindari kerusakan terhadap larik sensor gas, sensor temperatur pada sampel juga digunakan untuk menonaktifkan larik sensor gas. Gambar 7 menunjukkan diagram blok dari program yang digunakan pada sistem.

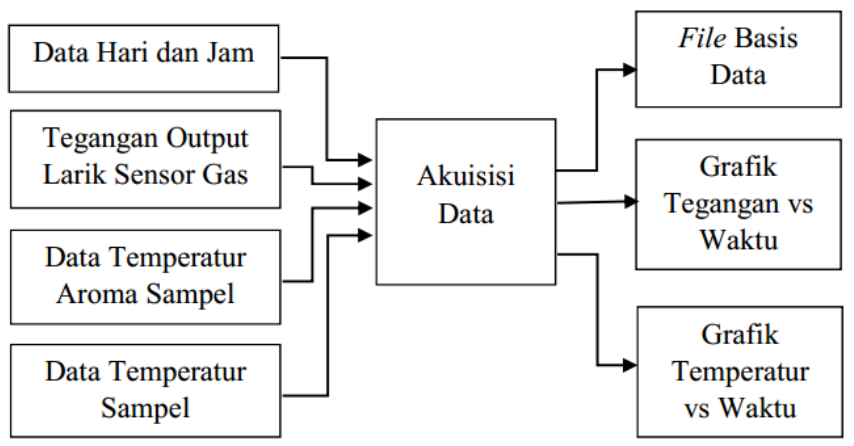

Gambar 7 Diagram blok rancangan program

\subsection{Implementasi Sistem}

Ruang sampel dan ruang sensor dapat dilihat pada Gambar 8 yang merupakan implementasi dari rancangan yang ada pada Gambar 6 Bahan yang digunakan untuk ruang 

sampel dan ruang sensor adalah bahan logam stainless steel dengan ketebalan untuk ruang sampel adalah $3 \mathrm{~mm}$ dan ketebalan untuk ruang sensor adalah $1 \mathrm{~mm}$.

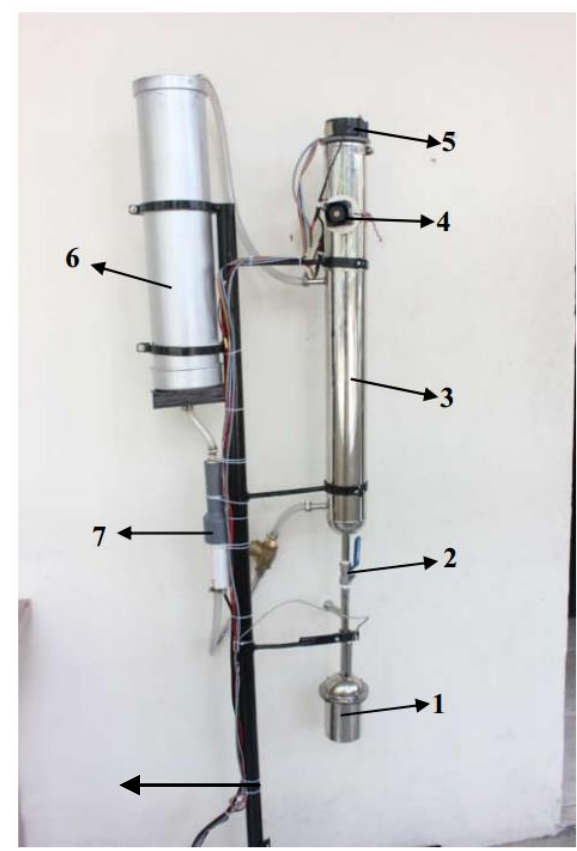

Gambar 8 Ruang Sampel dan Ruang Sensor (1) ruang sampel, (2) ball valve, (3) ruang sensor, (4) kipas K2 \& K3, (5) kipas K1, (6) penyimpan air pendingin, (7) pompa air

\subsection{Pengujian Sistem}

\section{HASIL DAN PEMBAHASAN}

Pengujian sistem diperlukan untuk mengetahui bahwa sistem siap digunakan, pengujian ini diawali dengan melihat respon masing-masing sensor terhadap aroma-aroma tertentu hingga pembacaan dari masing-masing sensor memperlihatkan keadaan yang stabil dari nilai output yang dihasilkan. Selain melihat respon sensor, dalam pengujian ini juga dilakukan uji repeatability pada tegangan keluaran sensor. Uji repeatability berfungsi untuk mengetahui pengulangan pembacaan dari tegangan keluaran sensor[10].

Setelah uji repeatability dilaksanakan, untuk mencari ciri dari aroma sampel dilakukan proses ekstraksi ciri dengan persamaan (1). Selanjutnya dilakukan analisis multivariant untuk mengetahui korelasi dari beberapa variasi sampel jamak (multivariant) agar dapat diklasifikasi. Langkah terakhir yang ditempuh adalah pengklasifikasian ciri menggunakan metoda PCA (Principal Component Analysis) untuk dapat melihat pola ciri yang terbentuk dan juga melihat efisiensi dari pembacaan sensor.

\subsection{Pengujian Sampel}

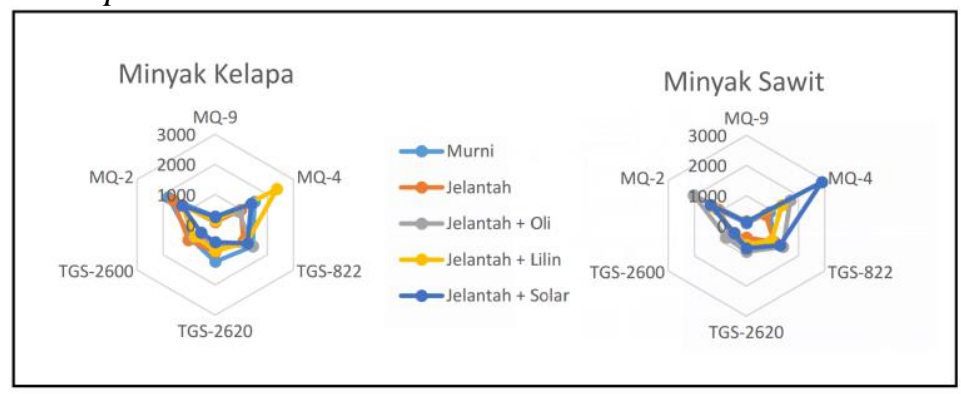

Gambar 9 Grafik radar hasil percobaan 

Gambar 9 merupakan grafik radar perbandingan nilai rerata pembacaan tegangan keluaran sensor terhadap sampel minyak goreng. Dari grafik radar untuk sampel kelapa sawit, diketahui bahwa sensor MQ-4 memiliki kecenderungan mendeteksi aroma dari uap sampel campuran jelantah sawit dengan solar dengan nilai sebesar $2894.92 \mathrm{mV}$. Uap sampel campuran jelantah sawit dengan oli bekas dapat dideteksi aromanya secara maksimal oleh sebagian besar sensor yang digunakan yaitu sensor TGS-822 sebesar $1401.86 \mathrm{mV}$, oleh sensor TGS-2620 sebesar $861.42 \mathrm{mV}$, oleh sensor TGS-2600 sebesar $775.18 \mathrm{mV}$, dan yang menampakkan respon yang paling signifikan yaitu sensor MQ-2 sebesar $2025.86 \mathrm{mV}$. Sensor MQ-9 tidak mampu melakukan pembacaan secara maksimal untuk semua sampel dan memiliki rerata nilai pembacaan sebesar $124.4 \mathrm{mV}$ untuk semua sampel minyak goreng jenis minyak sawit.

Untuk sampel jenis minyak kelapa, sensor MQ-4 memiliki kecenderungan untuk mendeteksi aroma uap dari sampel campuran jelantah kelapa dengan lilin dengan nilai sebesar $2359.84 \mathrm{mV}$. Sensor TGS-2620 memiliki kecenderungan untuk mendeteksi aroma uap sampel minyak kelapa murni sebesar $1226.96 \mathrm{mV}$. Seperti halnya yang terjadi pada pengujian dengan sampel minyak goreng jenis minyak sawit, untuk sensor MQ-9 tidak menunjukkan nilai pembacaan tegangan keluaran yang maksimal dan hanya berkisar pada nilai rerata sebesar 181.4 $\mathrm{mV}$.

\subsection{Pengolahan Data Menggunakan Metode PCA (Principal Component Analysis)}

Analisis menggunakan PCA pada penelitian ini dibagi atas dua sampel, yakni untuk sampel minyak goreng jenis minyak sawit dan sampel minyak goreng jenis minyak kelapa

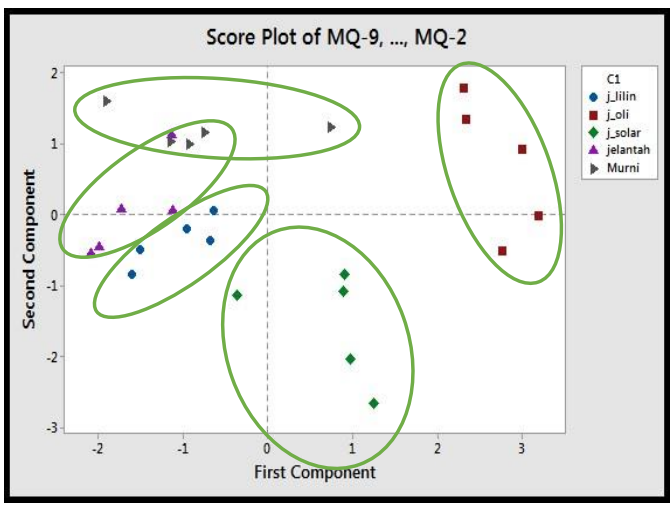

a

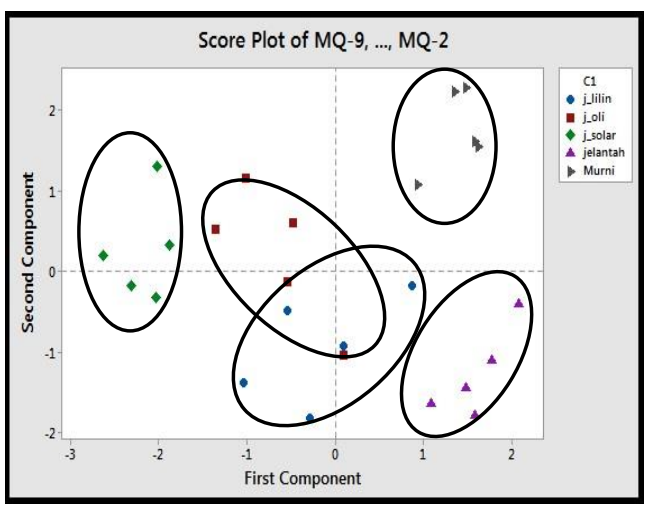

b

Gambar 10 Score plot hasil analisis PCA untuk sampel minyak goreng

Hasil score plot setelah data minyak sawit dianalisis menggunakan PCA diperlihatkan pada Gambar 10a. Sedangkan untuk sampel jenis minyak kelapa pada gambar 10b. Dari Gambar 10a dapat dilihat bahwa sampel jelantah minyak sawit yang dicampur dengan oli memiliki koordinat paling jauh dengan persebaran data yang cukup lebar. Hal yang sama juga ditemukan pada sampel jelantah minyak sawit yang dicampur dengan solar. Persebaran data yang saling menghimpun ditemukan pada sampel minyak sawit murni, jelantah minyak sawit dan jelantah minyak sawit yang dicampur dengan lilin. Terdapat irisan variabel sampel minyak sawit murni dengan variabel sampel jelantah minyak sawit, hal tersebut dapat diasumsikan karena paritas kandungan dari jelantah minyak sawit dengan jelantah minyak sawit.

Dari score plot pada gambar 10b diketahui bahwa sebagian besar variabel sampel minyak kelapa dapat terpisah dan saling mengelompok dengan persebaran data yang cukup 

lebar. Variabel sampel jelantah minyak kelapa yang dicampur dengan oli bekas beririsan terhadap variabel sampel jelantah minyak kelapa yang dicampur dengan lilin, namun hanya 3 data variabel tersebut yang saling beririsan. Hal tersebut diasumsikan karena sebuah data sampel yang berupa campuran jelantah minyak kelapa dengan oli bekas mengeluarkan aroma uap yang terbaca oleh larik sensor sebagai sampel jelantah minyak kelapa yang dicampur dengan lilin.

\section{KESIMPULAN}

Dari hasil penelitian yang telah dilakukan maka dapat diambil kesimpulan yaitu hasil pengujian dan pengolahan dengan metode Principal Component Analysis (PCA) menunjukkan bahwa electronic nose yang dibuat mampu mengklasifikasi minyak goreng jenis minyak kelapa dan minyak sawit murni dengan minyak goreng jenis minyak kelapa dan minyak sawit campuran namun terdapat beberapa data yang saling beririsan

\section{SARAN}

Penelitian lebih lanjut diharapkan dapat memperbaiki kekurangan yang ada dan diharapkan dapat mengembangkan apa yang telah dilakukan pada penelitian ini. Untuk itu disarankan hal-hal berikut :

1. Sebaiknya dilakukan penambahan jumlah sensor yang digunakan karena semakin banyak jumlah sensor yang digunakan, maka kepekaan sistem terhadap berbagai macam bau lebih tinggi.

2. Perlu dilakukan analisis lebih lanjut menggunakan gas chromatography untuk mengetahui komposisi gas yang terdapat dalam minyak goreng murni dan minyak goreng campuran.

\section{DAFTAR PUSTAKA}

[1] Dewi, Mega T.I dan Nurul H., 2012, Peningkatan Mutu Minyak Goreng Curah Menggunakan Adsorben Bentoit Teraktivasi, UNESA Journal of Chemistry, Vol 1, No 2., Departemen Kimia, Universitas Negeri Surabaya, Surabaya.

[2] Widayat S dan Haryani K, 2006, Optimasi Proses Adsorbsi Minyak Goreng Bekas dengan Adsorben Zeolit Alam, Studi Pengurangan Bilangan Asam, Jurnal Teknik Gelagar, Vol. 17, 77-82.

[3] Ketaren, S., 2005, Minyak dan Lemak Pangan, UI Press, Jakarta.

[4] SNI, 2013, Minyak Goreng, 3741-2013, Badan Standardisasi Nasional.

[5] Julianus D, 2006, Optimasi Proses Pembuatan Biodiesel dari Minyak Jelantah, Jurusan Teknik Kimia, UKI Paulus, Makassar.

[6] Guillen, M. D., dan Goicoechea, E., 2008, Formation of Oxygenated $\alpha, \beta$ Unsaturated Aldehydes and other Toxic Compounds in Sunflower Oil Oxydation at Room Temperature in Closed Receptacles, Food Chemistry, 111, 157-164.

[7] Uriarte, P.S., dan Guillen, M.D., 2010, Formation of Toxic Alkylbenzenes in Edible Oils Submitted to Frying Temperature: Influence of Oil Composition in Main Components and Heating Time, Food Reasearch International, Volume 43, Issue 8, 2161-2170.

[8] Triyana, K., Agustika D K., Hardoyono F., dan Chotimah., 2012, Penerapan Metode Ekstraksi Ciri Berbasis Transformasi Wavelet Diskrit untuk Meningkatkan Unjuk Kerja Electronic Nose, Prosiding Pertemuan Ilmiah XXVI HFI Jateng \& DIY, Purworejo 14 April 2012.

[9] Pearce, T. C., Schiffman, S.S., Nagle, H. T. dan Gardner, J. W., 2014, Handbook of Machine Olfaction: Electronic Nose Technology, WILEY-VCH, United Kingdom. 

[10] Lelono D., Triyana K, Hartati S., Amalinda F., Kaltsum U., Usuman I., 2011, Rancang Bangun Prototipe Sensor Rasa Elektronik Berbasis Membran Selektif Ion, Jurusan Ilmu Komputer dan Elektronika, FMIPA UGM, Yogyakarta. 